\title{
PENGARUH EKSTRAK BATANG SERAI (Cymbopogon citratus) TERHADAP PERTUMBUHAN BAKTERI Edwardsiella tarda SECARA IN VITRO
}

\section{EFFECT OF EXTRACT LEMON GRASS (Cymbopogon citratus) IN VITRO METHODS ON GROWTH OF BACTERIA Edwardsiella tarda}

\author{
Zulfadhli $^{1 *}$, Ika Andila ${ }^{2}$, Farah Diana ${ }^{1}$, Rinawati ${ }^{3}$ \\ ${ }^{1}$ Jurusan Akuakultur, Fakultas Perikanan dan Ilmu Kelautan, Universitas Teuku Umar \\ ${ }^{2}$ Jurusan Perikanan, Fakultas Perikanan dan Ilmu Kelautan, Universitas Teuku Umar \\ ${ }^{3}$ Jurusan Kesehatan Masyarakat, Fakultas Kesehatan Masyarakat, Universitas Teuku Umar \\ *Korespondensi: zulfadhli@utu.ac.id
}

\begin{abstract}
ABSTRAK
Penelitian ini bertujuan untuk mengetahui pengaruh ekstrak batang serai (Cymbopogon citratus) terhadap pertumbuhan bakteri edwarsiella tarda secara in vitro. Penelitian dilaksanakan pada bulan September sampai Desember 2016, bertempat di Laboratorium Hayati dan Laboratorium Mikrobiologi MIPA Unsyiah. Penelitian ini bersifat eksperimen dengan rancangan acak lengkap (RAL), dengan 3 perlakuan yaitu: $\mathrm{K}=$ kontrol, $\mathrm{P}_{1}=400 \mathrm{ppm}, \mathrm{P}_{2}=600 \mathrm{ppm}$, dan $\mathrm{P}_{3}=800 \mathrm{ppm}$. Hasil uji fitokimia menunjukkan bahwa kandungan zat aktif yang terdapat dalam batang serai ialah steroid, terpenoid, saponin, flavonoid, tanin dan fenolik. Ekstrak batang serai mampu menghambat pertumbuhan bakteri edwarsiella tarda berdasarkan hasil uji daya hambat. Diameter rata-rata zona hambat yang diperoleh adalah $\mathrm{P}_{1}=21 \mathrm{~mm}, \mathrm{P}_{2}=18 \mathrm{~mm}, \mathrm{P}_{3}=14 \mathrm{~mm}$, dan $\mathrm{K}=0 \mathrm{~mm}$.
\end{abstract}

Kata kunci: Cymbopogon citratus, Edwarsiella tarda, in vitro, Pertumbuhan.

\begin{abstract}
This study aims to determine the effect of citronella extract on the growth of edwarsiella tarda bacteria in vitro. The study was conducted from September to December 2016, at the Biological Laboratory and Microbiology Laboratory of the Faculty of Math and Science Unsyiah. This research is experimental with complete randomized design (RAL), with 3 treatment that is: $\mathrm{K}=$ control, P1 $=400 \mathrm{ppm}, \mathrm{P} 2=600 \mathrm{ppm}$, and P3 $=800 \mathrm{ppm}$. The results of phytochemical tests showed that the active substances contained in lemongrass steroids, terpenoids, saponins, flavonoids, tannins and phenolic. Lemongrass extract is able to inhibit the growth of edwarsiella tarda bacteria based on the inhibitory test results. The mean inhibitory zone diameter obtained was $\mathrm{P} 1=21 \mathrm{~mm}, \mathrm{P} 2=18 \mathrm{~mm}, \mathrm{P} 3=14 \mathrm{~mm}$, and $\mathrm{K}=0 \mathrm{~mm}$.
\end{abstract}

Keywords: Cymbopogon citratus, Edwarsiella tarda, in vitro, growth

\section{PENDAHULUAN}

Masalah yang sering dihadapi dalam kegiatan budidaya ikan adalah adanya penyakit pada ikan yang bersifat patogenik baik dari golongan parasit, jamur, bakteri, atau virus. Berkembangnya penyakit dalam proses budidaya ikan pada dasarnya disebabkan terjadinya ketidakseimbangan interaksi antara faktor lingkungan, mikroba air dan ikan yang merubah kualitas air menjadi buruk sehingga mikroba patogen berkembang dalam air dan menyerang ikan budidaya (Kordi, 2004). Satu diantara berbagai penyakit ikan yang berbahaya adalah penyakit Edwarsiella tarda yang disebabkan oleh bakteri dari genus Edwardsiella.

Pengendalian Edwarsiella tarda awalnya banyak menggunakan bahan kimia seperti obat-obatan (antibiotik). Namun saat ini pemerintah membatasi pengunaan bahan kimia karena dapat menimbulkan residu pada ikan dan membahayakan kesehatan konsumen

*Fakultas Perikanan dan Ilmu Kelautan, Universitas Teuku Umar

Korespondensi : Jurusan Akuakultur, Fakultas Perikanan dan Ilmu Kelautan, Universitas Teuku Umar, Kampus UTU Meulaboh, Alue Peunyareng 23615, Telp: +62 85359854557, email: zulfadhli@utu.ac.id 
apabila dikonsumsi. Penggunaan bahan kimia dalam jangka waktu lama menyebabkan mikroba resisten dan menimbulkan pencemaran lingkungan. Untuk menghindari penggunaan bahan kimia maupun antibiotik, alternatif lain untuk pengendalian penyakit ini adalah pemanfaatan antimikroba yang bersifat alami dari tumbuhan (Mulyani et al., 2013). Aktivitas antimikroba dapat dihasilkan oleh tumbuhan dan potensi antimikroba dari bahan alam lebih aman namun memiliki fungsi serta aktivitas yang tidak kalah dari antibiotik atau bahan kimia lainnya. Satu dari berbagai bahan alam adalah batang serai (Cymbopogon citratus) yang diduga mengandung senyawa aktif sebagai antimikroba. Menurut Verawati et al. (2013), senyawa aktif yang terdapat dalam serai bumbu (Andropogon citratus D.C) adalah alkaloid, flavonoid, tanin, kuinon, dan terpenoid. Berdasarkan uraian diatas perlu dilakukan penelitian lebih lanjut terhadap potensi antimikroba dalam batang serai (Cymbopogon citratus) dan efektivitas batang serai dalam menghambat pertumbuhan bakteri Edwarsiella tarda.

\section{METODE PENELITIAN}

Penelitian ini dilaksanakan pada bulan September sampai Desember 2016. Proses uji fitokimia batang serai dilakukan di Laboratorium Hayati MIPA Unsyiah dan Tahap proses uji antibakteri (In vitro) dilakukan di Laboratorium Mikrobiologi MIPA Unsyiah.

Alat dan bahan yang digunakan diantaranya cawan petri, laminar air flow laf01, pipet tetes, gelas ukur, tabung reaksi, rak tabung, inkubator, jarum ose, rotary evaporator, refrigerator, timbangan analitik $0,01 \mathrm{gr}$, auto clave $121{ }^{\circ} \mathrm{C}$, vortex, hot plate dan mikroskop binoculer. Sedangkan bahan yang digunakan adalah batang serai, bakteri Edwarsiella tarda, nutrien agar (NA), nutrien broth (NB), larutan $\mathrm{FeCl}_{3} 1 \%$, aquades, etanol $70 \%$, alumunium foil, kapas, kertas cakram, kertas label, dan kertas saring whatman no.42.

Penelitian ini bersifat eksperimen dengan menggunakan Rancangan Acak Lengkap (RAL) satu faktor, terdiri atas 3 perlakuan (masing-masing 3 kali ulangan). Perlakuan yang diberikan yaitu:

$\mathrm{K}:$ Tanpa perlakuan $=0 \mathrm{ppm}$

P1 : Perlakuan ekstrak batang serai $=400 \mathrm{ppm}$

P2 : Perlakuan ekstrak batang serai $=600 \mathrm{ppm}$
P3 : Perlakuan ekstrak batang serai $=800 \mathrm{ppm}$

Tahapan penelitian meliputi ekstrak batang serai, uji fitokimia, dan uji in vitro. Ekstraksi dilakukan dengan metode maserasi menggunakan pelarut etanol. Tahapan pengujian fitokimia dilakukan berdasarkan metode Harborne (1987). Tahap-tahap uji in vitro meliputi:

1. Sterilisasi alat dan bahan,

2. Pengenceran ekstrak batang serai dengan akuades sesuai perlakuan (kontrol, $\mathrm{P} 1=400$ ppm, $\mathrm{P} 2=600 \mathrm{ppm}, \mathrm{P} 3=800 \mathrm{ppm}$ ),

3. Pembuatan media TSA sebagai media pertumbuhan bakteri Edwarsiella tarda,

4. Penanaman bakteri ke dalam cawan petri yang telah berisi media NA menggunakan metode cawan sebar (Spread plate),

5. Menempelkan kertas cakram (diameter 6 $\mathrm{mm})$ yang telah direndam dalam larutan ekstrak batang serai dengan berbagai kosentrasi di permukaan media agar NA dalam cawan petri,

6. Cawan petri tersebut kemudian diinkubasi pada suhu $37^{\circ} \mathrm{C}$ selama $18-24$ jam,

7. Melakukan pengamatan dengan melihat zona bening yang terbentuk disekitar kertas cakram, sebagai zona hambat terhadap pertumbuhan bakteri Edwarsiella tarda.

Parameter yang diamati dalam penelitian ini adalah zona hambat pertumbuhan bakteri. Pengukuran diameter zona hambat yang terbentuk diukur menggunakan jangka sorong. Data yang diperoleh selama penelitian dikelompokkan dan ditabulasikan dalam bentuk tabel. Selanjutnya data dianalisis secara statistik (ANOVA).

\section{HASIL DAN PEMBAHASAN}

\section{Senyawa Kimia Batang Serai}

Kandungan kimia yang terdapat dalam ekstrak batang serai dianalisis golongan senyawanya dengan tes uji warna dengan beberapa pereaksi untuk golongan senyawa alkaloid, steroid, terpenoid, saponin, flavonoid, tanin dan fenolik. 
Tabel 1. Hasil ujifitokimia ekstrak batang serai (Cymbopogon citratus)

\begin{tabular}{lccc}
\hline \multicolumn{1}{c}{ Kandungan Kimia } & Reagen & Batang Serai & Hasil Pengamatan \\
\hline Alkaloid & Mayer & - & Endapan Putih \\
& Wagner & - & Endapan Coklat \\
& Dragendorff & - & Endapan Merah \\
Steroid & Uji Liebermann & + & Hijau \\
Terpenoid & Uji Liebermann & + & Merah \\
Saponin & Pengocokan & + & Berbusa \\
Flavonoid & $0,5 \mathrm{~g} \mathrm{Mg} \mathrm{dan} \mathrm{HCl}$ & + & Merah Muda \\
Tanin & $\mathrm{FeCl}_{3}$ & + & Hijau Kehitaman \\
Fenolik & Etanol $+\mathrm{FeCl}_{3}$ & + & Biru Kehitaman \\
\hline
\end{tabular}

Ket: (+) menunjukkan hasil positif dan (-) menunjukkan hasil negative

Tabel 2. Klasifikasi kemampuan hambat senyawa antimikroba berdasarkan luas zona hambat

\begin{tabular}{ccc}
\hline Perlakuan & Luas Zona Hambat $(\mathbf{m m})$ & Kemampuan Hambat \\
\hline K & 0 & Lemah \\
P1 & 21 & Sangat Kuat \\
P2 & 18 & Kuat \\
P3 & 14 & Kuat \\
\hline
\end{tabular}

Berdasarkan uji fitokimia, senyawa aktif yang terkandung dalam batang serai adalah steroid, terpenoid, saponin, flavonoid, tanin dan fenolik (Tabel 1). Verawati et al., (2013) dalam penelitiannya melaporkan bahwa senyawa aktif yang terkandung dalam serai bumbu (Andropogon citratus D.C) adalah alkaloid, flavonoid, tanin, kuinon, dan terpenoid. Sedangkan menurut Rita \& Ningtyas (2012), menyatakan bahwa Cymbopogon nardus memiliki kandungan saponin, tanin, kuinon dan steroid. Perbedaan senyawa aktif yang terdeteksi dalam tumbuhan bisa disebabkan oleh perbedaan penggunaan pereaksi/pelarut.

\section{Uji in vitro}

Berdasarkan hasil pengujian secara in vitro terhadap ekstrak batang serai (Cymbopogon citratus), diketahui bahwa ekstrak batang serai mampu menghambat pertumbuhan bakteri Edwarsiella tarda yang disebar pada media NA. Hal ini diketahui dengan terbentuknya zona hambat setelah media diinkubasi selama 24 jam, ini menunjukkan bahwa dalam ekstrak batang serai mengandung senyawa aktif yang sifat antibakteri.

Terbentuknya area bening di sekitar kertas cakram menunjukkan adanya daya kerja antibakteri. Zona hambat yang kecil menunjukkan adanya aktifitas antibakteri yang rendah, sedangkan zona hambat yang besar menunjukkan adanya aktifitas antibakteri yang tinggi. Tinggi rendahnya diameter zona hambat yang terbentuk diduga karena perbedaan kosentrasi senyawa aktif yang terdapat pada kertas cakram.

Diameter rata-rata zona hambat maksimal terdapat pada perlakuan P1 yaitu 21 $\mathrm{mm}$, diikuti $\mathrm{P} 2$ dengan rata-rata $18 \mathrm{~mm}$, selanjutnya P3 yaitu $14 \mathrm{~mm}$ dan Kontrol (K) sebesar $0 \mathrm{~mm}$. Nilai zona hambat diatas menunjukkan bahwa kemampuan ekstrak batang serai tergolong kuat. Menurut Arora \& Bhardwaj (1997), aktivitas antimikroba dikategorikan memiliki tingkat sensitivitas tinggi apabila diameter zona hambat mencapai $>12 \mathrm{~mm}$. Kategori tingkat sensitivitas sedang apabila ekstrak mampu memberikan diameter zona hambat sekitar 9-12 mm. Kategori tingkat sensitivitas rendah, apabila diameter berkisar antara 6-9 $\mathrm{mm}$ dan resisten apabila < $6 \mathrm{~mm}$.

Kemampuan ekstrak batang serai dalam menghambat pertumbuhan bakteri Edwardsiella tarda telah diuji secara in vitro. Hasil uji tersebut didapatkan dosis ekstrak batang serai yang efektif dalam menghambat pertumbuhan bakteri Edwardsiella tarda yaitu konsentrasi $400 \mathrm{ppm}$ dengan diameter zona hambat $21 \mathrm{~mm}$. Menurut Naik et al., (2010), bahwa Cymbopogon citratus mampu menghambat pertumbuhan bakteri: Staphylococcus aureus, Bacillus cereus, 
Bacillus subtilis, Escherichia coli, Klebsiella pneumoniae, Pseudomonas aeruginosa.
Kordi KMG. 2004. Penaggulangan Hama dan Penyakit Ikan. Jakarta. Rineka Cipta
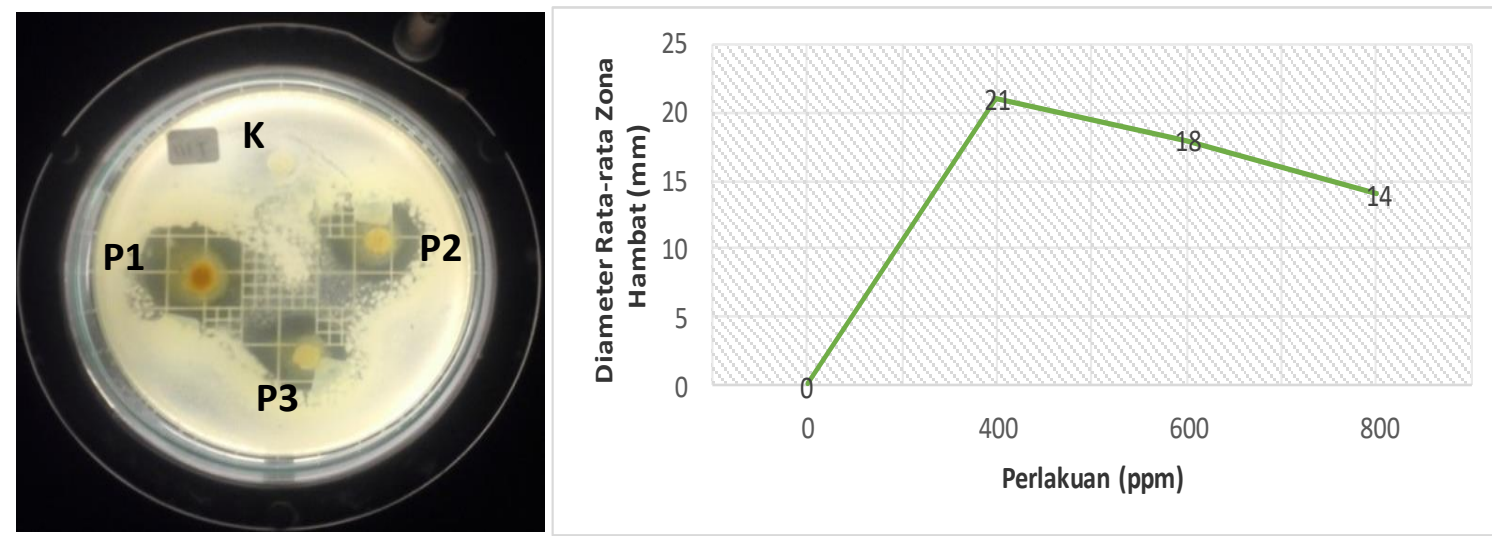

Gambar 1. Diameter zona hambat ekstrak batang serai terhadap bakteri Edwarsiella tarda

Katzung (1989) dalam Naiborhu (2002) menjelaskan bahwa mekanisme kerja senyawa antimikroba dimulai dengan penghambatan sintesis dinding sel, perubahan permeabilitas membran sel atau transpor aktif melalui membran sel, penghambatan sintesis protein yaitu penghambatan penerjemahan dan transkripsi material genetik dan penghambatan sintesis asam nukleat. Kerusakan membran sel menyebabkan tidak berlangsungnya transport senyawa dan ion ke dalam sel bakteri sehingga bakteri mengalami kekurangan nutrisi yang diperlukan bagi pertumbuhannya dan akhirnya mati. Maharti (2007) menambahkan bahwa kecepatan dan efisiensi kerusakan bakteri oleh senyawa antibakteri dipengaruhi oleh suhu, pH, waktu, konsentrasi, stabilitas zat aktif, masa pengeraman dan aktifitas metabolis bakteri.

\section{KESIMPULAN}

Batang serai (Cymbopogon citratus) memiliki kandungan senyawa aktif yaitu steroid, terpenoid, saponin, flavonoid, tanin dan fenolik. Senyawa aktif dalam batang serai mampu menghambat pertumbuhan bakteri Edwardsiella tarda. Dosis ekstrak yang efektif pada pelakuan $\mathrm{P}_{1}=400 \mathrm{ppm}$ dengan diameter zona hambat $21 \mathrm{~mm}$.

\section{DAFTAR PUSTAKA}

Arora DS. Bhardwaj. 1997. Antibacterial activity of some medicinal plants. Geo. Bioscience (24): 127- 131.

Harborne JB. 1987. Metode Fitokimia. Bandung. Institut Teknologi Bandung. dan Penerbit Bina Adiaksara.

Maharti ID. 2007. Efek antibakteri ekstrak daging buah avokad (Persea americana) terhadap Steptococus [Skripsi]. Jakarta. Universitas Indonesia.

Mulyani Y, Bachtiar E, Kurnia AMU. 2013. Peranan senyawa metabolit sekunder tumbuhan mangrove terhadap infeksi bakteri Aeromonas hydrophila pada ikan mas (Cyprinus carpio L). Jurnal Akuatika 4(1): 1-9.

Naiborhu PE. 2002. Ekstraksi dan manfaat ekstrak mangrove (Sonneratia alba dan Sonneratia cselaris) sebagai bahan alami antibakterial pada patogen udang windu Penaeus Monodon, Vibrio harveyi. [Tesis]. Bogor. Institut Pertanian Bogor.

Naik MI, Fomda BA, Jaykumar E, Bhat JA. 2010. Antibacterial activity og Lemongrass (Cymbopogon citratus) oil against some selected pathogenic bacterias. Asian Pasific Journal of Tropical Medicine. 535-538.

Verawati PA, Anam K, dan Kusrini D. 2013. Identifikasi kandungan kimia etanol serai bumbu (Andropogon citratus D.C) dan uji efektivitas repelen terhadap nyamuk Aedes aegypti. Jurnal Sains dan Matematika 21(1):20-24. 